\title{
The Belief in and Veneration of Ancestors in Akan Traditional Thought: Finding Values for Human Well-being
}

\author{
Stephen Nkansah Morgan \\ ORCID iD: https://orcid.org/0000-0002-4480-7952
}

\author{
Beatrice Okyere-Manu \\ ORCID iD: https://orcid.org/0000-0003-2735-9227
}

\section{Abstract}

Traditional Africans' belief in and veneration of ancestors is an almost ubiquitous, long-held and widely known, for it is deeply entrenched in the African metaphysical worldview itself. This belief in and veneration of ancestors is characterised by strong moral undertone. This moral undertone involves an implicit indication that individual members of communities must live exemplary lives in accordance with the ethos of the community. Living according to the ethos is among the conditions for attaining the prestige of being elevated to an ancestor after one's death. The aim of this paper is to gain an understanding of the metaphysical and moral demands connected to ancestor veneration. With this understanding, the paper suggests values that can promote a better way for humans to coexist, and indicates a moral sense of the responsibility people should hold towards each other. The paper's focal aim is to expose what it considers to be the moral undertones or features associated with a belief in and veneration of ancestors, mainly from traditional Akan perspectives. The paper also considers how principles and values of Akan communitarianism can be espoused to promote human well-being. It is the position of the paper that the metaphysical and, especially, the moral underpinning of ancestor veneration in the traditional Akan society, can provide values that can serve as catalysts for the furtherance of human well-being.

Keywords: Ancestor, African morality, African values, human well-being, African worldview, communitarianism 


\section{Introduction}

Supreme God, who is alone great, upon whom men lean and do not fall, receive this wine and drink. Earth goddess, whose day of worship is Thursday, receive this wine and drink. Spirits of our ancestors, receive this wine and drink (Gyekye 1995:68).

The quote above is one of the many prayers of libation of the Akan people of Ghana. The prayer gives insight into an aspect of the ontology, or the metaphysical worldview, of the traditional Akan people, that is, their belief in God and in the existence of a plurality of supernatural beings, including the spirits of ancestors. Generally, Africans living south of the Sahara are known to be very religious. Evidently, their religiosity permeates almost every aspect of their daily lives, sometimes making it difficult to draw a distinctive line between what is cultural or social, and what is religious. However, Zulu (2002:478) believes there is no such dichotomy at all. His position is corroborated by that of Teffo and Roux (2002:167), who claim that the distinction between the natural and the supernatural does not exist for the African metaphysician; they state, '[a]nother dichotomy which plays an important part in Western reflection, the distinction between the material and the spiritual, has no place either in African thinking'.

The African belief in and reverence for ancestors are rooted in the African people's ontological worldview itself. Ugwuanyi (2011:112-113) notes that the spirits of ancestors, as well as the spirits of other divinities, can dwell in various aspects of the natural environment, including hills, forests, rocks, trees, mountains and animals, and whatever people consider to be home of a spirit is usually set apart as a sacred place, where people make offerings to worship that particular spirit.

According to Peter Sarpong (1974:33) only a few traditional societies in Africa lack an organised approach to venerating the dead. Among the tribes that do not venerate the dead are the small tribe of the Nuer, in the southern part of Sudan, and other Nilotes, like the Dinka, the Shilluk and the Anuak. These tribes aside, the belief in and reverence for ancestors play an integral role in the socio-religious practices of sub-Saharan African people in general. Ancestors, are regarded as the spirits of departed elders, who live in a world 
similar and parallel to that of the world of the living (Gyekye 2002:25). They work to promote the good of the living, and keep watch over humans' morals. Ugwuanyi (2011:112) regards ancestors as spirits of dead human beings who had lived extraordinary lives while alive, and thus, after death, were given a place among the divinities. These beliefs in ancestors and the held perceptions about them contain some degree of moral undertone, for as Dzobo (1992:231) notes, not just anyone who has died can be called an ancestor.

The aim of this paper, therefore, is to come to a better understanding of these moral and metaphysical notions of ancestors and, based on this understanding, suggest values that can promote better human coexistence and a moral sense of responsibility between people. The paper considers what the moral undertones or characteristics attached to the belief in and veneration of ancestors are, and how some of these principles can be embraced to improve human well-being. Overall, it is the position of the paper that the metaphysical and, especially, the moral underpinning of ancestor veneration can uncover values that can serve as a remedy for the current day depreciation of humanism, and can be utilised to promote human well-being.

This article is a philosophical or a meta-analysis of existing literature, and not an empirical study. This means that it critically analyses and evaluates the Akan notion of ancestor, human well-being and related topics and subtopics as they are presented in both primary and secondary texts. The paper begins with an investigation of the metaphysical worldview of the Akan people, in an attempt to locate the place of ancestors in their socio-religious lives, and some of the characteristics they associate with their belief in ancestors. It also takes a brief look at Akan communitarianism, in a bid to reach an understanding of what the notion of well-being means to the Akans. This will be followed by an examination of the moral connotations and implications surrounding the beliefs in and the veneration of ancestors. The fourth section will link the salient points of the preceding sections to show how both the metaphysical belief and, especially, the moral undertone associated with the Akan belief in and veneration of ancestors can be used to frame a condition that promotes human well-being. It is important to state here that, although most of the examples and references used are based on the beliefs and experiences of traditional Akan people of Ghana, it does not suggest that their applications are limited to these people only. As Christopher Agulanna (2010:284) notes, 'While Africans may differ in respect of certain aspects of their cultures, they nevertheless share those aspects that are universal in nature'. 


\section{The Place of Ancestors in Akan Ontology}

As indicated above, the African ontology of the world is composed of both physical and nonphysical beings, lined up in a hierarchy of importance and power. This idea, of course, is made evident in many works on the indigenous beliefs of African people (Gyekye 1995; Wiredu 2010). Both Wiredu and Gyekye explain that the traditional Akan people of Ghana believe in a hierarchy of beings, with the supreme being, God, at the apex. After God, in a descending order, are found various kinds of spirits (smaller gods and the spirits of ancestors). Some of these spirits are believed to reside in some part of nature, notably trees, mountains, animals and rivers. After these spirits, is the human species, which is, in turn, followed by lower animals, vegetation, and the rest of inanimate objects, in a descending order. The nature of God in the Akan belief system can be deduced from the qualities ascribed to Him; the supreme being, who occupies the summit of the hierarchy, and who is considered to be the source of all life and the ultimate creator of all that there is. He is, thus, given the ultimate veneration and worship. As Wiredu (2010:35) points out, the supreme being is considered to be in charge of the world order, and attributes that are commonly ascribed to him are omniscient, omnibenevolent, and omnipotent. A sense of dependency, trust, and unconditional reverence is evident throughout Akan attitudes to the supreme being. Danquah (1968) explains that the Akan people identify God as, among others, the father of all, the creator, and as one whose nature is good.

Among the plurality of beings, the human species appears to play a key role in the general framework of this physical and nonphysical ontology; immediately above the human species are the spirits, which, Wiredu (2010:36) explains, are recognised as having the capacity to aid or to destroy human beings. They do this in ways that are beyond the causes and effects recognisable in everyday life. Wiredu continues that human beings are cautious, and try their best to establish good rapport with the more susceptible spirits, which usually involves rituals of supplication, sugar-coated by flattery and praise. The spirits of ancestors, as we will learn, serve as the ultimate aspiration of the living for after they pass on from the physical world.

Just below the human species are the lower animals, the vegetation and the rest of inanimate objects, both natural and artificial. These lower beings or entities are used by the human species for its daily survival needs, including its need for food, water, clothes, medicine, and shelter. Thus, from the African metaphysical outlook, it appears that all the beings above the human species 
(which are nonphysical beings) on the hierarchy are there to ensure the spiritual well-being of the human species; whereas the beings below the human species (which are all physical beings), ensures its physical well-being. However, for some, drawing a line between the physical and nonphysical aspects of Akan ontology would be quite an imprecise or evasive line, given what is known of Akan ontology. As Gyekye (1995) explains, in traditional Akan ontology, 'there is no distinction between the sensible (perceivable) world and the nonsensible (nonperceivable) world in the sense of the latter being real and the former being unreal, as in other metaphysical systems'. As such, different from other metaphysical systems, there is a strong interconnection, and interrelationship between everything constituent of nature, whether physical or nonphysical.

In considering some of the features of the ancestors as held by indigenous Akan people, Wiredu (2010:36) reports on the special position occupied by ancestors among nonphysical beings: 'They are not the most powerful, but they are, in the great majority of African societies, the most loved and respected'. Ancestors are believed to dwell in a nonphysical world comparable, in many ways, to the physical world that they left behind. They are also believed to engage in similar roles, professions and positions as those they held in the land of the living just before their death. These ancestors have the power to interact with, and do, indeed, interact regularly with the living. In this regard, Teffo and Roux (2002:168) remark that,

The ancestors interact with mortals, and because the world of the ancestors is ontologically both analogous and contiguous to that of the mortals, that is, there is no difference in kind between these worlds (as was pointed out, it is all one and the same world) there is no logical problem with this interaction; category problems do not arise; the actions of the ancestors are believed to be within the regular pattern of events. The immortals merely happen to occupy a higher status in the order of things than mortals.

Sarpong (1974:38) corroborates this notion, and indicates that 'a chief here is a chief there, a farmer here is a farmer there'. For the Akan, death is not the end of one's life, but a transition from one state of existence to another, elevated state of existence. Sarpong (1973:22) describes the meaning of death for the Akan: 
Death is regarded as the occasion when the deceased person sets out on a journey to the underworld or spirit world to which his ancestors have already gone ... In death one only changes his earthly mode of existence to another, in fact, better one. In the life after death, there is no cheating, there is no physical pain or deformity, there are no evil intentions or machinations ... part of man's personality survives after death. He calls this 'ghost' or in a more respectable terminology 'ancestor'.

Furthermore, the concerns of the ancestors are limited to the affairs of a specific family, clan or lineage; however, if an ancestor had been a ruler, then his or her concerns may extend to all the lineages in his or her town or kingdom, though not beyond (Wiredu 2012:32; Sarpong 1974:34). The ancestors are also credited with extra-human powers, which can be tapped into by the living to their benefit. Despite the special place and the role the ancestors play in the lives of the Akan people, and even though they hold ancestors in high esteem, it is important to mention that ancestors are not worshipped by African people. This is an error or misrepresentation by some scholars, Western and African alike. This error has been observed by the likes of Zulu, Wiredu, Dzobo and Sarpong. Zulu (2002:476), for instance, remarks that ancestors are considered to be human beings, and Africans worship God alone. Thus, for him, to claim Africans worship ancestors is to make a false generalisation, because, to worship a human being in the real sense of the word, is foreign to the African. Wiredu (2010:35) agrees with this position, by suggesting that it may be impossible to find a directly corresponding word for worship in many African languages. Therefore, he describes the allusion to ancestor worship as a misnomer for ancestor veneration (Wiredu 2012:32). To this end, Zulu, Wiredu and Sarpong would prefer to describe the African belief in ancestors as a 'reverence' or 'veneration' of ancestors, rather than the worship of ancestors. This reverence or veneration, Wiredu (2010:35) holds, is nothing more than an accentuated form of the respect given to the living elders of a community.

\section{The Moral Undertone of the Akan Belief in Ancestors}

Morality, as we know, deals with right and wrong behaviour and serves as a guiding principle according to which people are supposed to live their lives. Morality is needed to ensure peace, harmony and mutual coexistence of people 
in societies. In this section, the paper identifies some features of the traditional Akan belief in and veneration of ancestors that express the moral connotations therein, and require individuals to act in accordance with the community's sense of morality if they are to qualify as ancestors. In doing this, the paper is not arguing that traditional Akan people find their sense of morality in their ancestors. Indeed, several authors, including Wiredu and Gyekye, have shown that, despite evidence of a high level of religiosity and supernaturalism embedded in traditional African societies, their source of moral norms and precepts does not stem from religion. Gyekye (1995:131), for instance, in commenting about the Akan concept of the good, writes that, "what is morally good is not that which is commanded by God or any spiritual being; what is right is not that which is pleasing to a spiritual being or in accordance with the will of such being'. Traditional African ethics, it has often been argued, is rooted, rather, in humanism, that is, in that which leads to the betterment or well-being of humanity or the community. To this, Gyekye (1995:132) states concerning the Akan:

In Akan moral thought the sole criterion of goodness is the welfare or well-being of the community ... Within the framework of Akan social and humanistic ethics, what is morally good is generally that which promotes social welfare, solidarity, and harmony in human relationships. Moral value in the Akan system is determined in terms of its consequences for mankind and society. 'Good' is thus identical with the welfare of the society, which is expected to include the welfare of the individual.

Wiredu (2010:35) describes Akan ethics as a 'rational humanistic ethic', of which the criteria of good conduct are founded on 'the quest for the impartial harmonization of human interests'. Despite the humanistic origins of morality in traditional Akan societies, the role of the supernatural, that is, God and the other spiritual beings, is not completely absent. Gyekye (1995:141) himself acknowledges this, when he notes that God and other spiritual beings, even though they are not the people's source of morality, do, in a way, act as their motivation to act morally, or influence how people respond to moral norms. 'Since some of this sanction derive in the Akan system from religious beliefs, it follows that religion cannot be completely banished from the practice of morality', Gyekye writes, '[my] conclusion, then, is that in terms of behaviour, 
of responses to moral norms and rules, Akan morality cannot be said to be wholly independent of religion' ${ }^{1}$. Menkiti (2004:131), similarly, notes that, although morality for the African is not based on the supernatural, 'the moral domain admittedly contains a ubiquitous reference to ancestors'.

What, then, is the moral undertone of the belief in ancestors? Part of the answer is found in what Africans believe it takes to become an ancestor. Death, for the Akan, is a transition to the world of ancestors, yet not everyone who has transitioned gains the title, honour or prestige of becoming an ancestor to a family, clan or a community. Thus, Sarpong (1974:34) notes that dying, alone, is not enough to earn you the prestigious honour of an ancestor. For one to merit such an honour after one's death, he opines, one must fulfil certain conditions while alive. What are the conditions for ancestorship? Dzobo (1992:231) notes that Nananom (the Akan word for ancestors) is, first and foremost, a moral title and is earned by living virtuously before one's death; it is also conferred upon living chiefs and elders of the society - people who are considered to be moral paragons. Pobee (1976:8 as cited in Zulu 2002:479) gives more insight into this held belief:

The most important aspect in this whole belief in ancestors is that not everyone becomes an ancestor after death; it is only people who had a credible life as heads of families, clans or tribes. For example, among the Akan people the man who was morally bankrupt is disqualified from being an ancestor; so is the one who dies tragically or through some loathsome disease such as leprosy or madness.

The moral undertone is indicated by the use of words such as 'credible life' and 'moral bankruptcy'. Dickson (1984:198) notes that, 'those who became ancestors must have lived exemplary lives; it is not everyone who dies who becomes ancestor, so that the cult of the dead is not to be equated with that of

${ }^{1}$ Gyekye makes a distinction between two types of morality. The first type refers to the sources and principles of morality (which, he argues, does not originate from religion, but is humanistic in nature). The second type of morality refers to the patterns of behavior, motivation and response to moral norms and rules (which, he argues, is somewhat influenced by religion, that is, by God and spiritual beings). It is to the sense of the second type of morality that we refer to in this sentence. 
the ancestors'. This indicates clearly that moral uprightness is an important requirement for becoming an ancestor after death. We refer to this requirement as the 'moral uprightness criterion'.

In addition to the moral uprightness criterion, a second part of the moral undertone in connection with ancestor veneration in the traditional African setting, originates from the belief that part of the duty of an ancestor is to enforce the morality of the people. As Wiredu (2010:35) points out, ancestors have moral authority they exercise by enforcing predetermined moral norms. As we have established, ancestors are not the source of the people's moral codes, instead, they are believed to enforce already established moral norms of their people. This, they do, to ensure that living members of their ancestry do not engage in immoral behaviours that would bring disgrace to the clan's name. To do this, the ancestors are believed to have the power to bless those who do well and curse those who falter in character. The curses may take the form of sudden diseases that are incurable without the help of a spiritualist. To this, Wiredu (2010:36) explains further that:

the ancestors may be called the extra-mundane guardians of morality; their entire concern is to watch over the affairs of the living members of their families, rewarding right conduct and punishing its opposite, with unquestioned justice, while, at all times, working for their wellbeing. It is on this ground that the ancestors are so highly venerated.

Dzobo, likewise, observes in this regard that, because of the perceived moral and positive attributes of the ancestors, their life patterns and the values and principles they esteem are used as normative standards of conduct for the people. Dzobo (1992:232) reports that,

The ancestors likewise exercise moral constraints in the behaviour of the living through the periodic rituals which remind people of what they stand for. They are able to play this role not because they have become 'spirits' or 'ghosts', but because they have become internalized superegos as well as moral authorities. Thus, the exemplary way they lived can be used to help others grow and pursue the ideal life.

The 'moral enforcement duty' explained above accentuates the importance of 
the moral uprightness criterion, because it will not make for sound reasoning to think of someone who never lived a morally upright life in the land of the living, to be an enforcer of the people's morals after their death, or for their lives to be used as an instance of an exemplary life led for others to emulate the contradiction will be too glaring to ignore. Thus, Wiredu (2012:30) is right to point out that the rules of conduct that ancestors are believed to help enforce are the same rules that the ancestors themselves lived by, or were required to live by when they were alive.

The paper demonstrates that the moral undertone or connotation embedded within the traditional Akan belief in ancestors is made up of two closely related factors. In the first place, it is found in the moral uprightness requirement of becoming an ancestor, which denotes that only those who have led exemplary lives can qualify to be ancestors. Secondly, it is found in the held belief that ancestors are 'moral enforcers' of behaviour of members of their living lineage.

The question, then, remains: What does it mean for the Akan to live an exemplary life? Dzobo (1992:233f) provides information on what can be described as the demands or criteria of a life lived exemplarily in a traditional Akan community. He reports that the traits of an exemplary life that qualify anyone to become an ancestor after death are being married, having children, living with good health, and dying of natural causes in one's old age. Dzobo holds that marriage and childbearing are to be considered the first signs of an exemplary life according to the African understanding. The reason for this requirement, he reports, is that a bachelor or spinster does not help to increase the number of their relatives, as customs demand. One may be tempted to think that one does not need to be married to have children; however, we have to bear in mind that bearing a child without being married is abhorrent to traditional Akan societies. This marriage condition, thus, imply that, should one choose not to marry, he or she automatically becomes disqualified to become an ancestor. Dzobo reports further that being married, alone, is not enough for one to qualify to become an ancestor. In addition, the couple should bear children to continue the family lineage. Thus, a childless person, even if married, will not be acknowledged as an ancestor upon his or her death. This is because, for the traditional Akan people, a person's most important goal as an individual and member of the clan, is to multiply and increase the size of the clan. Failure to do so is considered failure in life, and no person who is a failure can be an ancestor. 
The third demand of an exemplary life is good health. This, according to Dzobo, requires an aspiring ancestor 'to have a sound mind in a sound body'. The individual must not suffer from any of the diseases considered to be 'unclean', because unclean diseases are considered to be the result of curses by the gods for immoral behaviour, including breaking a taboo, or neglecting one's customary duty, which could have repercussions for the entire community. Diseases that are considered unclean, Dzobo notes, may include leprosy, dropsy, epilepsy, madness, sleeping sickness, smallpox, and blindness. Anyone who comes into contact with any of these diseases is regarded morally unclean and, as such, unfit to be an ancestor of the people.

The fourth criterion for an exemplary life relates to one's circumstances of death. Dzobo reports that the Akan generally believe that some manners of death denigrate a person, while others enhance a person's status. Obviously, death by any of the unclean diseases listed above is a disqualifier. Dzobo adds that death by suicide, by drowning, death as a result of vehicular accidents or any accidental death, are not considered honourable. Also, death as a result of falling in war through acts of cowardice, like retreating from the enemy, is unacceptable death. Dying in any of these ways excludes an individual from becoming an ancestor. As Sarpong (1974:35) explains, these kinds of deaths are considered to be the result of a person's hidden crimes. Instead, what is preferred are deaths that are the result of bravery in defending one's community, or death in old age. These are when one is believed to have lived a fulfilled and destined life.

Interestingly, Sarpong (1974:34) states that attaining adulthood is the first condition for becoming an ancestor. He writes:

When the Ghanaian is pouring libation and you listen to the names of the dead which he mentions, you will notice that names of babies, boys or girls are omitted. The names that are mentioned are those of adults, chiefs and queen mothers. The first condition therefore is adulthood.

Even though there seems to be a difference between what Dzobo says is the first condition (that is, marriage and childbearing) and what Sarpong claims, the difference tends to fade when one considers that Sarpong does not define an adult in terms of age, but in terms of being married. Sarpong (1974:34) notes that, among the Ashanti (a major subgroup of the Akan), an adult is almost by 
definition a married person. As such, a married teenager is considered to be an adult, while an unmarried sixty -year-old person is not.

Despite these conditions, there are some notable exceptions. It is possible for an adult person who has shown bravery in war or in defence of his or her people to be conferred the title of an ancestor, despite being unmarried or having no child. This is because the act of bravery, and sacrificing one's life for the community is a highly regarded virtue. Secondly, as noted by Sarpong (1974:34) concerning the Ashantis', if an unmarried young man is made a chief or a leader of his people, that man is regarded as an adult, and he qualifies to be an ancestor if he does right by his people. He is considered to be married, partly because of the 'stool wives', that is, women permanently attached to a stool as the ceremonial wives of any incumbent ruler who occupies the stool at any point in time - the young unmarried king is be regarded as 'ceremoniously' married, so to speak.

Additionally, Dzobo draws attention to other moral etiquette and character traits that add to the making of an exemplary life. An aspiring ancestor, he notes, should not be someone who is known for insulting others, particularly in public. The person should not be a thief, an adulterer, a talkative person, an alcoholic, an extravagant type or a person who harbours malice towards another. The person is, rather, expected to exhibit such positive traits as being hardworking, kind, loving, pacific, respectful, merciful, and a keeper of promises. Likewise, he or she must keep the right sort of company, speak the truth and be someone who can be trusted to keep secrets, among other character traits. Only such a person is considered someone worth emulating, a moral paragon, so to speak. As Dzobo (1992:234) explains, if one is not good in life, how can one's 'ghost' be any good?

\section{On the Notion of Well-being}

The notion of well-being, in general, presents a philosophical conundrum that space will not allow this paper to delve into fully. As such, the concern of this section is to introduce readers to what an Akan understanding of human wellbeing involves. Stephen Campbell (2016:402) notes that the notion of wellbeing is typically about 'what makes a life go well or poorly for the one who is living it'. He mentions some four notable theories of well-being: The theory of hedonism claims that well-being is all about what leads to pleasure and avoids pain. The desire-fulfilment theory holds that well-being is about the 
fulfilment of our actual or idealised desires. The objective-list theory asserts that well-being is to be found in a plurality of things while the perfectionist theory claims that well-being depends on developing and exercising an individual's natural capacities.

The focus of these Western theories of well-being on the individual agent is glaring. In the African setting, including the Akan, an understanding of individual well-being is deeply rooted in a shared community life; it is a notion of well-being deeply rooted in the theory of communitarianism, by which Akan societies are characterised. Gyekye (1995:155) defines communalism or communitarianism as 'the doctrine that the group (that is, the society) constitutes the focus of the activities of the individual members of the society'. He understands communitarianism to be a doctrine about social organisation and relations, which essentially sprout from the Akan concept of humanism. The Akan concept of humanism, Gyekye notes, basically ensures the welfare and interests of each member of the society. Gyekye (1997), however, argues that Akan societies are characterised by a theory of a 'moderate communitarianism', which allows for the promotion of the good of the individual as well as the good of the community, rather than a 'radical communitarianism', which suppresses individual needs.

Some of the basic tenets of Akan communitarian and its humanistic attitude is that the individual needs assistance from and a connection with others in order to attain or satisfy basic needs. The philosophy enjoins individuals to live a life of harmony and corporation with others, in order to attain the good of individuals in line with the good of their community. The sociability of humans is recognised to be a result of basic human nature, though it is also regarded as that which leads to personal well-being and worth (Gyekye 1995:157).

Deeply embedded in this communitarian attitude is the idea of the 'common good'. Gyekye (1997:45) defines the common good as 'a good that is common to individual human beings ... a good the possession of which is essential for the ordinary or basic functioning of the individual in a human society'. This idea of human well-being has its foundation in what promotes the good of all in the society, and is expressed in numerous Akan proverbs, such as the proverb, obi yiye firi obi, which means the well-being of a person depends upon another person.

In relation to the above, Antwi (2017:96) notes that, in traditional Akan societies, the normative concept of a person develops from how a person is 
understood in terms of his or her relations with others. This conception of wellbeing of traditional Akan societies is, of course, closely aligned with what is known in traditional southern African communities as the principle of Ubuntu/Boto or Ukama, which is an ideology and a philosophy of life that is recognised and promoted in every aspect of traditional and modern life. Just like the quest to seek the well-being of all, or to promote the common good of the community, Ubuntu 'implies that humanness is derived from our relatedness with others, not only with those currently living but also through past and future generations' (Murove 2009:315). Thus, Ubuntu requires members of a community to look out for each other's interests, because one's progress as an individual is interconnected with the progress of others as a group. It is this notion of human well-being embedded in the communitarian attitude of the traditional Akan people that the paper advocates for.

\section{Ancestor Veneration and Aspiration as a Vehicle for the Well-being of Humans}

The central question remaining now is how we can use these features surrounding the belief and veneration of ancestors to foster human well-being in the sense explained in the previous section. An important point worth noting here is that there exists within the Akan traditional culture a desire by its people to be joined to the ranks of ancestors upon their demise (Wiredu 2012: 32; Wiredu 2010:35). For Wiredu, 'ancestorship is simply the crowning phase of human existence' (Wiredu 1996:48). Thus, becoming an ancestor after one's life on earth is considered to be one of the greatest honours that can be bestowed upon a person. However, there is more to the desire of becoming an ancestor. The aspiration to be an ancestor is not just a quest to have one's name immortalised; it is essentially an opportunity for privileged people to continue contributing to the welfare of their people, even in the afterlife. Since it is the desire of individuals in traditional African society to become ancestors after their demise, and since the criteria for becoming an ancestor requires of individuals to have lived a virtuous, moral life, individuals are, thus, motivated to live their lives in their community in a manner that is acceptable to society, and which includes living in peace and harmony with others in the community.

In addition to the living conferring on the deceased the honourable title of ancestor based upon their moral uprightness during their lifetime on earth, the motivation to live a morally worthy life in one's lifetime is also essential if 
one wants to be accepted by the ancestral spirits in the land of the ancestors. Sarpong (1974:22) describes the journey one makes to the ancestral world after death. He writes:

The journey [from the land of the living to the land of the living-dead] is arduous and unavoidable. One who sets foot on it, cannot and should not come back, except as a respected ancestor spirit. But if he had been particularly wicked in his life time [e.a.], or something had gone wrong before his journey or in the course of it, he might not be admitted to the world of spirits.

What this means is that living a virtuous life in one's lifetime on earth is not only motivated by the pursuit to meet the requirement of ancestorship, but also by the quest to please the spirits of the ancestors who will admit the dead into their midst in the ancestral world.

Even if someone does not desire or aspire to become an ancestor after death, and even if someone does not necessarily care about being accepted into the ancestral world after one's demise, there is a belief that the ancestors are capable of punishing living members should they conduct themselves in a way that brings the name of the clan into disrepute. As was explained earlier, the ancestors are credited with the power to reward and to punish. They reward those whose lives conform to established norms, that is, those that promote the good of the clan, and punish people who live detestable lifestyles. Their punishment can be in the form of incurable strange illnesses, or as other misfortunes, including accidents resulting in premature death. Surely, anyone will dread punishment from their ancestors, and this dread can serve as an incentive for people to want to live a life worthy of praise or, at least, to avoid lifestyles that can bring harm to their clan and community.

It is the position of this paper that the aspiration to become an ancestor after death, coupled with the moral and non-moral requirements for making this possible, lead us to some virtues that can be used to promote human wellbeing. The fear of earning the curse of the ancestors or not being accepted in the ancestral world because of one's bad deeds on earth can serve as motivations for individual members to aspire to do well in their community, not just in terms of attaining personal laurels, but to promote better human-tohuman relationships in accordance with the Akan communitarian principles of human well-being, which seeks to promote the common good of the society. 
Again, considering what goes into living an exemplary life as detailed by Dzobo and Sarpong, it is evident that the general idea behind these conditions is to ensure that individuals in the community live lives that depict maturity in thoughts and in deeds. These conditions ensure that individuals live a life of responsibility worthy of emulation by the younger generation, which is what it means to leave a mark. It may be argued that using marriage and childbearing as part of what it means to have lived an exemplary lifestyle, in our contemporary time, may not be effective, since a person's sense of maturity or responsibility is not determined by marriage or by the bearing of children. However, the principle found here, it should be argued, is not to be placed on marriage and child bearing only, but, instead, should be considered as a prompt to do what one can to promote the cause of humanity, and avoiding the annihilation of humanity in the long run. Looking at it from this perspective, of course, coincides with the very importance the Akan people place on marriage and procreation, which is, to ensure the continuation of the family lineage and ancestry. It also emphasises the importance and relevance of marriage in such a communitarian society.

The other marks of an exemplary life, i.e., to live a healthy life and to die of a natural cause in one's old age, is undeniably relevant in today's time. As Dzobo noted, a would-be ancestor is expected to be of sound mind and of sound body. In these days of unhealthy lifestyle choices that have led to many new diseases that kill people before they reach their prime, these two requirements for ancestorship serve as motivation to live a healthy lifestyle, and ought to be considered as a welcoming call that can promote better human well-being. The paper need not go into the details of the benefits of having a sound mind and a sound body, since these benefits are generally well known. A long and a healthy life can enable those who seek it to take care of their children and contribute their share to their community and to their nation. The alternative is to become a burden on the family and community due to illhealth. Accidents can occur at any time, whether one is healthy or not, yet the point is to live a cautious and moderated lifestyle, to avoid avoidable accidents, so that one can live the full extent of his or her life and serve his or her community to the fullest. Such a call resonates with the communitarian character of the Akan people, which encourages individuals to live a life of altruism and care for others.

A look at, what we call, other 'auxiliary' traits of an exemplary life required of an aspiring ancestor, provides more values for mutual living that 
can promote human well-being, in consonance with the Akan communitarian ethos. Dzobo, as we have seen, indicates that an aspiring ancestor should not be a person given to insults, thievery, adultery, alcoholism, or an extravagant lifestyle, among others. Such an aspirant should, instead, be truthful, hardworking, kind, loving, respectful, trustworthy, and merciful, a keeper of promises, and someone who keeps good company. In effect, the underlying principle here, is for individuals to eschew vices and embrace virtues that facilitate healthy coexistence among members of the community. Undoubtedly, where peaceful coexistence exists among citizens, individuals can enjoy a healthy state of mind and experience rapid socio-economic progress and development, which are important factors for the physiological well-being of any individual.

Interestingly, in indicating the traits of an exemplary life or the conditions for becoming an ancestor, Dzobo notes that wealth does not appear on the list - that is to say, that the amount of wealth one has or does not have is not a condition for becoming an ancestor. Instead, as Dzobo (1992:234) states, "it is the use of wealth that determines whether its owner should be called nana or not. It is the generous use of wealth that is always encouraged and qualifies a person to be called nana'. This approach, as Dzobo explains, encourages sharing, not just with the living, but also with the living dead (that is, the ancestors). This is exhibited through the sprinkling of water or drink on the ground for the ancestors when someone is eating or drinking. A principle that encourages the sharing of one's wealth with others, which is a very important principle for social well-being. In traditional Akan communities, wealthy individuals who are known to be self-centred are seldomly admired. In the spirit of communal living, for the common good, and in line with the principles of Ubuntu, any successful individual should benefit others with their wealth. This is not to be interpreted, as may be done by some, that the acquisition of wealth is abhorred or seen as a vice in these communities; rather, the principle of sharing should be seen as a way to ensure that those who have gained advantage in the community do not neglect the less privileged.

According to Dzobo (1992:235), to the Akan, life is a process of neverending human and communal relationships, which are defined in terms of reciprocal obligations and privileges. Death, therefore, does not end the obligations of the living to the living dead, or the privileges that the living enjoy from their forebears. Even the relationship between God and man, Dzobo maintains, is defined in terms of reciprocal obligations and blessings. The 
living are, therefore, continually interested in the well-being of the living dead and the living dead are interested in the well-being of the living. As it was shown earlier, there is a close interconnection and collaboration between the physical realm and the nonphysical realm.

The aforementioned principles derived from ancestor veneration in traditional Akan societies are very plausible, for they are embedded in the communitarian attitude of African people. Menkiti (2004:130) notes that:

Ancestorhood, as we know, is part of the continuing process of elderhood, with those who have achieved its status still tied to the living, still invoked as members of an ongoing moral community. This community, which embraces both the living and the dead, not surprisingly, is bound by considerations of mutual concernpaternal care on the part of the ancestors and filial piety on the part of the living.

Thus, the well-being of the individual and of the community is expressed in mutual concern, social ties and sociability that extend beyond the living and, as Agulanna (2010:286) notes, 'human well-being, peace and order are only achievable in a communal or social setting'. If that is the case, then it is the paper's position that ancestor belief and veneration provide a catalyst that can promote the attainment of human well-being that is not based in individualism, but based in the people's communitarian character.

\section{Conclusion}

As stated by Gyekye (1995:41), 'communitarianism immediately sees the individual as an inherently communal being, embedded in a context of social relationships and interdependence, never as an isolated individual'. If this is the case, a search for human well-being should start, essentially and firstly, in those actions that promote these positive communitarian attributes. The reverence for ancestors is, no doubt, losing its essence and impact in these modern times, partly as a result of the continuous spread of Christianity and Islam, and with the growth of reliance on scientific explanations. This decline in the reverence for ancestors is heightened by the rise of postmodernism, with its array of new ideologies that are both inharmonious and adversative to many traditionally held beliefs. Nevertheless, it is the position of this paper that there 
are values and principles embedded in the belief in and veneration of ancestors by traditional Akan societies that are not outdated, and still hold value for modern times that can promote human well-being.

The paper noted that belief in and veneration of ancestors come with an embedded moral undertone, which is seen mainly in what the paper tagged as the 'moral uprightness criterion' (a condition for becoming an ancestor) and the 'moral enforcement duty' (the power of ancestors over the living). The paper identified some moral principles found within these requirements for becoming an ancestor that can help in promoting a strong sense of community among individuals in accordance with the communitarian character of the African people. The paper maintained that the quest to become an ancestor after death is a good motivator to encourage individuals to live virtuous, moral lives, worthy of emulation by the younger generation, and can safeguard peaceful coexistence. In addition, the condition for ancestorship requires of individuals to live exemplary lives, a life of responsibility and a show of maturity if they are to secure a place in the ancestral world. Thus, the paper maintains that, these requirements or conditions for becoming an ancestor in traditional African communities produce certain virtues and moral principles that could remedy the continuous decline in our sense of humanity. Such a move could serve as a catalyst to improve human well-being, for, as Menkiti (2004:131) points out concerning African communitarian societies, 'morality is seen in light of what 'fits', what leads to societal harmonization and village flourishing'. Also, if Gyekye is right in his claim that the 'good', for the African, is considered identical to the welfare of society, then the belief in and veneration of ancestors has positive principles that can help attain this good.

\section{References}

Agulanna, C. 2010. Community and Human Well-being in an African Culture.

Trames 14, 64/59, 3: 282 - 298. https://doi.org/10.3176/tr.2010.3.05

Antwi, J.K. 2017. The Value of a Person in Akan Traditional Life and Thought:

A Contemporary Inquiry. European Journal of Interdisciplinary Studies

1,3: 93 - 101. https://doi.org/10.26417/ejis.v3i2.p94-102

Campbell, S. 2016. The Concept of Well-being. In Fletcher, G. (ed.): The

Routledge Handbook of Philosophy of Well-Being. London: Routledge.

Danquah, J.B. 1968. The Akan Doctrine of God: A Fragment of Gold Coast 
Ethics and Religion. $2^{\text {nd }}$ Edition. London: Frank Cass and Company. https://doi.org/10.2307/1594909

Dickson, K. 1984. Theology in Africa. London: Longmans \& Todd.

Dzobo, N.K. 1992. Values in a Changing Society: Man, Ancestors and God.

In Wiredu, K. \& K. Gyekye (eds.): Person and Community. (Ghanaian

Philosophical Studies, I.) Washington D.C.: Council of Research in

Values and Philosophy.

Gyekye, K. 1997. Tradition and Modernity: Philosophical Reflections on the

African Experience. Oxford: Oxford University Press.

Gyekye, K. 1995. An Essay on African Philosophical Thought: The Akan

Conceptual Scheme. Philadelphia: Temple University Press.

Gyekye, K. 2002. On Decolonizing African Religions. In Coetzee, P.H. \& A.P.J. Roux (eds.): The African Philosophy Reader. $2^{\text {nd }}$ Edition. London: Routledge.

Menkiti, I. 2004. Physical and Metaphysical Understanding: Nature, Agency, and Causation in African Traditional Thought. In Brown, L.M. (ed.): African Philosophy: New and Traditional Perspectives. Oxford: Oxford University Press.

Murove, F. 2009. An African Environmental Ethic Based on the Concepts of Ukama and Ubuntu. In Murove, F.M. (ed.): African Ethics: An Anthology of Comparative and Applied Ethics. Scottsville: University of KwaZuluNatal Press.

Sarpong, P. 1974. Ghana in Retrospect: Some Aspects of Ghanaian Culture.

Tema: Ghana Publishing Corporation.

Teffo, L. \& A. Roux 2002. Metaphysical Thinking in Africa. In Coetzee, P.H.

\& A.P.J. Roux (eds.): The African Philosophy Reader. $2^{\text {nd }}$ Edition.

London: Routledge.

Ugwuanyi, L.O. 2011. Advancing Environmental Ethics through the African

World-view. Mediterranean Journal of Social Sciences 2,4: 107 - 114.

Wiredu, K. 2012. African Religions. In Meister, C. \& P. Copan (eds.):

Routledge Companion to Philosophy of Religion. London \& New York:

Routledge. Available at

https://www.routledgehandbooks.com/doi/10.4324/9780203813010.ch3

(Accessed on: 04 Jun 2018).

Wiredu, K. 2010. African Religions from a Philosophical Point of View. In Taliaferro, C., P. Draper \& P. Quinn, Philip (eds.): A Companion to Philosophy of Religion. $2^{\text {nd }}$ Edition. West Sussex: Blackwell Publishing. 
Wiredu, K. 1996. Cultural Universals and Particulars: An African Perspective. Bloomington: Indiana University Press.

Zulu, E. 2002. Reverence for Ancestors in Africa: Interpretation of the $5^{\text {th }}$ Commandment from an African Perspective. Scriptura 81: 476 - 482. https://doi.org/10.7833/81-0-749

Stephen Nkansah Morgan $\mathrm{PhD}$ Candidate Applied Ethics Studies School of Religion, Philosophy and Classics University of KwaZulu-Natal Greatmorgan2003@gmail.com

Beatrice D. Okyere-Manu Applied Ethics Studies School of Religion, Philosophy and Classics University of KwaZulu-Natal Okyere-Manv@ukzn.ac.za 